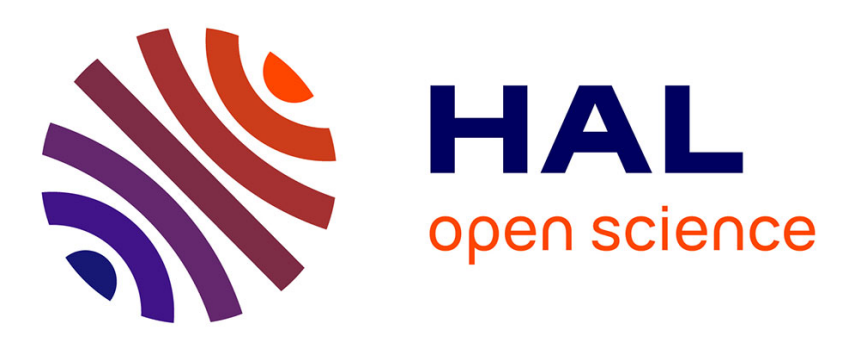

\title{
Humusica 2, article 11: Histic humus systems and forms - Epihisto intergrades and dynamics
}

\author{
Augusto Zanella, Jean-François Ponge, Rein de Waal, Bas van Delft, Maria de
}

Nobili, Chiara Ferronato, Livia Vittori Antisari, Gilmo Vianello, Bernard Jabiol

\section{To cite this version:}

Augusto Zanella, Jean-François Ponge, Rein de Waal, Bas van Delft, Maria de Nobili, et al.. Humusica 2, article 11: Histic humus systems and forms - Epihisto intergrades and dynamics. Applied Soil Ecology, 2018, 122 (Part 2), pp.162-169. 10.1016/j.apsoil.2017.03.001 . hal-01665345

\section{HAL Id: hal-01665345 \\ https://hal.science/hal-01665345}

Submitted on 15 Dec 2017

HAL is a multi-disciplinary open access archive for the deposit and dissemination of scientific research documents, whether they are published or not. The documents may come from teaching and research institutions in France or abroad, or from public or private research centers.
L'archive ouverte pluridisciplinaire HAL, est destinée au dépôt et à la diffusion de documents scientifiques de niveau recherche, publiés ou non, émanant des établissements d'enseignement et de recherche français ou étrangers, des laboratoires publics ou privés. 


\title{
Humusica 2, article 11: Histic humus systems and forms-Epihisto intergrades and dynamics
}

\author{
Augusto Zanella ${ }^{a}$, Jean-François Ponge ${ }^{b,}{ }^{,}$, Rein De Waal ${ }^{c}$, Bas Van Delft ${ }^{c}$, Maria De Nobili ${ }^{d}$, Chiara \\ Ferronato $^{e}$, Livia Vittori Antisari ${ }^{e}$, Gilmo Vianello $^{e}$, Bernard Jabiol ${ }^{f}$ \\ a University of Padua, Padua, Italy \\ ${ }^{\mathrm{b}}$ Muséum National d'Histoire Naturelle, Paris, France \\ ${ }^{\mathrm{c}}$ University of Wageningen, Wageningen, The Netherlands \\ ${ }^{\mathrm{d}}$ University of Udine, Udine, Italy \\ e University of Bologna, Bologna, Italy \\ ${ }^{\mathrm{f}}$ AgroParisTech, Paris, France
}

Keywords: Histosols; Soil water dynamics; Humus; Biodegradation; Peats; Wetlands

\section{ABSTRACT}

The processes of formation and evolution of Histic humipedons are related to the soil/water dynamics. In a first part of the paper we present diagnostic features and horizons necessary for describing the intergrade humipedons existing between Histic and Hydro humipedons. Called Epihistic ("superficial" Histic), these humipedons are very common and help in better defining the relationships between plant and soil in semi-terrestrial environments. In a second part of the paper we set some information about biological activities and correlated environmental frames of Histic and Epihisto units. The article concludes with dynamic relationships between humipedons, describing them in fen or bog ecosystems, allowing the interpretation of complex wetlands. The present manuscript updates the description and classification of semi-terrestrial humus forms previously published by Zanella et al. (2011a, 2011b).

\footnotetext{
${ }^{*}$ Corresponding author.

E-mail addresses: augusto.zanella@unipd.it (A. Zanella), ponge@mnhn.fr (J.-F. Ponge), rein.dewaal@wur.nl (R. De Waal), bas.vandelft@wur.nl (B.Van Delft), maria.denobili@uniud.it (M. De Nobili), chiara.ferronato2@unibo.it (C. Ferronato), livia.vittori@unibo.it (L.V. Antisari), gilmo.vianello@unibo.it (G. Vianello), bernard.jabiol@agroparistech.fr (B. Jabiol).
} 


\section{Specific terms and diagnostic horizons}

Intergrades between Histic and Terrestrial humus systems are necessary for understanding the processes of litter transformation and soil formation in wet ecosystems (Fig. 1).

\subsection{Hydromorphic properties}

The prefix " $\mathrm{g}$ " indicates the presence of reductimorphic and/or oximorphic colours. Reductimorphic colours reflect permanently wet conditions (indicating the presence of soluble reduced iron: grey colours, bluish-green greys) while oximorphic colours reflect oxidizing conditions, as in the capillary fringe and in the surface horizons of soils with fluctuating groundwater levels. Oximorphic colours indicate the presence of insoluble oxidised iron: reddish brown, bright yellowish brown, orange, dark orange or pale yellow. Reductimorphic and oximorphic colours cover only some parts of the soil volume when hydromorphic properties are weakly expressed. Bluish-green and black colours are unstable and often oxidize to reddish brown within a few hours of exposure to air. Oximorphic colours at the inside of superficially grey soil aggregates indicate a recent and instable submersion of the aggregates. A hydromorphic horizon may be all grey in case of permanent submersion or more or less finely mottled grey and orange if sequences of phases of submersion/emersion occur.

\subsection{Hydromorphic organic horizons}

ORGANIC HORIZONS: organic horizons submerged and/or water-saturated for a nonprotracted period of the year (less than 6 months per year) and showing the effects of temporary anoxia; carbon content $20 \%$ or more (approximately $40 \%$ organic matter) by weight, in dry samples without living roots (Method: element analyser; ISO 10694, 1995). Horizons still under saturated circumstances or drained.

gOL, gOF, gOH (from hydromorphic Terrestrial horizons): hydric organic horizons formed under non-prolonged water saturation (less than 6 months), periodically water-saturated and showing the effects of temporary anoxia. A prefix letter " $\mathrm{g}$ ", written before the code of Terrestrial horizons, indicates the presence of hydromorphic properties: plant remains becoming dark, glued together and often coloured along leaf veins (more evident than usual) by black particles of humic component deposited here by water during immersion periods; humic component often dark grey or black, massive and plastic, may be structured in faunal droppings during aerated periods. Carbon content $\geq 20 \%$ by weight. Humic component less than $10 \%$ in volume (roots excluded) in gOL (Fig. 2), between 10 and $70 \%$ in gOF (Fig. 3) and more than $70 \%$ in gOH.

\subsection{Hydromorphic organic-mineral horizons}


ORGANIC-MINERAL HORIZON: submerged and/or water-saturated for a non-protracted period of the year (less than 6 months per year); carbon content generally less than 7\% by weight, in dry samples without living roots (Method: element analyser; ISO 10694, 1995).

gA (from terrestrial A horizon and "g" for hydromorphic properties): hydromorphic organicmineral horizon showing evident effects of temporary anoxia such as oxidation/reduction ironmottling colours (orange-red splashes within grey to bluish-grey mass) covering at least $1 / 3$ of the surface of the horizon profile; carbon content generally less than $7 \%$ by weight. All terrestrial $A$ horizons can show hydromorphic properties (gzoA, gnozA, gmaA, gmeA, gmiA, gmsA, gsgA, gamaA, gameA, gszoA). Sometimes these properties are only traces of past events and are not in accordance with the current hydrological situation. If carbon content is higher than $7 \%$ by weight, similarities with $\mathrm{mrA}$ or HS are possible. However, the structure of gmaA or gmeA horizons, mostly due to anecic and endogeic earthworms, and although partially destroyed by water, never becomes completely plastic and massive as in the mrA horizon; carbon content of gzoA, gnozA, gmaA, gmeA, gmiA, gmsA, gsgA, gamaA, gameA, gszoA never reaches $20 \%$, which is the case in every kind of HS horizon. If carbon content is higher than $7 \%$ by weight, similarities with anA or HS are possible. However, the structure of gmaA or gmeA horizons, mostly due to anecic and endogeic earthworms, and although partially destroyed by water, never becomes completely plastic and massive as in the anA horizon; carbon content of gmiA, gmsA and gsgA never reaches $20 \%$, which is the case in every kind of HS horizon.

anA (from "A" organic-mineral horizon and "an" "anmoor", strongly humified (or decomposed) peat): histic organic-mineral horizon (organic carbon, $\mathrm{OC} \geq 7 \%$ ) mostly formed under the action of microorganisms (actinomycetes), dark coloured, with plastic and massive structure when wet and granular to subangular blocky when dry, either high or low base-saturated.

Earthworms may be abundant in better aerated periods, but the typical structure of their droppings is rapidly destroyed by water immersion and permanence (Figs. 4 and 5), which allows this horizon to be distinguished from all types of hydromorphic $\mathrm{gA}$ in case of similitude in carbon content. Because of long periods of immersion, the oxidation of organic matter is dilatory, conferring a dark colour of partially oxidized organic matter to the horizon. When needed, a subdivision could be made under local circumstances (Van Delft et al., 2002). Most Anmoor mrA (including the slightly acid amorphic "glide-layers" that in Dutch classification are not considered Anmoor) have a content of OC between 8 and $25 \%$.Some of the Anmoors are dangling between organic-mineral (OC $\leq 20 \%)$ and organic (OC > $20 \%)$ horizons. Strictly applying therule $(O C \leq 20 \%)$, some anA $(20 \%<O C \leq 25 \%)$ would be classified as HS horizons, and the system interpreted as Saprimoor (large floodplains, large extended systems partly characterized by processes of sedimentation) instead of Anmoor (small rivers, brooks, small streams and floodplains, not in dynamic floods or inundations with fast currents). In these doubtful cases and exceptionally, we suggest to classify the horizon following the ecological determinant and to note between brackets the value of OC\% established with laboratory analysis. Example of small river with doubtful Anmoor system: (23)anA means anA with 23\% OC content.

\section{Names of Epihistic intergrades}


When concomitance of histic ( $\mathrm{H}$ or anA) and hydromorphic horizons ( $\mathrm{gOH}$ or/and $\mathrm{gA})$, the prefix "Epihisto" (from "Epi", superficial, and "Histic", submerged humus forms) is set before the name of the corresponding Histic form.

Examples of names of Epihistic Anmoors:

- Epihisto Anmoor = anA or IHS or HS/anA + gzoA or/and gOH

- Euanmoor $=a n A$; Epihisto Euanmoor $=$ anA + gzoA or gOF or gOH

- Limianmoor = IHS/anA; Epihisto Limieuanmoor =IHS/anA + gzoA or/and gOF and $\mathrm{gOH}$

- Saprianmoor = HS/anA; Epihisto Saprianmoor = HS/anA + gzoA or/and gOF and gOH

- Epihisto Saprimoor = HS thicker than anA + gzoA or gnozA/gAE or/and gOF and gOH

- EpihistoAmphianmoor = HS thicker than $\mathrm{HM}$ or HF + gzoA or gnozA or/and gOF or $\mathrm{gOH}$

- Epihisto Mesimoor = HM thicker than $\mathrm{HF}$ or $\mathrm{HS}+$ gzoA or gnozA or/and gOF and gOH

- Epihisto Fibrimoor $=\mathrm{HF}$ thicker than $\mathrm{HM}+$ gzoA or gnozA/gAE or/and gOF oand gOH

\section{Dynamic specificities}

Epihistic forms can be grouped according to the process of formation in three categories:

- stationary thin Histic forms in which decomposition matches accumulation of organic matter. They develop in mesotrophic environments such as groundwater fed areas, brookvalleys and wet depressions (rather common) and generate Epihistic Anmoor and Saprimoor;

- real initial forms generated as a consequence of a dynamic evolution from Terrestrial Hydro forms into Epihisto Histic soil conditions in different ways. Brookvalley example: change of a dynamic (erosive) wet environment (Hydro Mull fed by mesotrophic or eutrophic water) into a wet, non-dynamic, rainwater fed situation (Saprimoor), isolated from the stream channel. This could be caused by a change in the course of the stream channel;

- moist depressions (especially on sandy areas). Example: depression becoming wet because of an increasing stagnation of rainwater on an old terrestrial humus profile (Anmoor, Saprimoor);

- peat remnant-forms (change from Epihisto to Hydro). Example: brookvalleys and wet depressions after drainage (natural or artificial) with development of Hydro forms from Histic forms, through all possible Epihisto Fibri-, Amphi- Saprimoor and Anmoor;

- wet areas in which the toplayer is removed without drainage; in this case "gA" may be overlaying deeper organic $\mathrm{H}$ horizons;

- remnants of Histic forms because of peat-mining; 
- brackish situations: when the influence of fresh groundwater becomes more important, the peaty toplayer disappears. The process is typical for polders and other reclamations of tidal flats and grassland estuaries (forming Anmoor and Saprimoor).

If the transition from Terrestrial to Histic humipedons is short (few metres, less than $10 \mathrm{~m}$ ), the sequence often skips the Epihisto intergrade as shown in Fig. 6. On sea, river, lake sides, it is even possible to skip Epihisto and Histo humipedons, passing directly from Terrestrial Hydro to Aqueous systems (see Figure 1; and Humusica 2, article 12 for details on Aqueous systems).

\section{Simplified table of classification of Histic forms and Epihisto intergrades}

All encountered Epihistic humus forms are reported in Figure 7. Epihistic diagnostic horizons are reported on both sides of the table in the grey-green columns. Each main Histic system has been subdivided in two, three or four humus forms according to the thickness ratio of the composing diagnostic horizons and using the following prefixes:

- Fibri, Mesi, Humi and Sapri along a gradient of increasing biological activity and consequent transformation of the HF (fibric) horizon in an HS (sapric) horizon, passing through an intermediate level (HM);

- Limi indicates the units of Anmoor and Saprimoor having an IHS (limic) horizon;

- Eu indicates the typical Anmoor expressed by the anA horizon only.

A second level of classification is shown on Figure 7.

\section{Bioactivity of Histic humus systems and forms}

In water-saturated systems, the bioactivity, and with it the decomposition of organic plant residues, depend on water quantity, oxygen availability, water quality ( $\mathrm{pH}$, nutrients and bases) and quality of the peat itself, mineral content included. All these factors are closely related and form the complex which describes the main peat-forming systems (Stortelder et al., 1998).

The water quantity can be described in terms of water level and oxygen availability, which vary with frequency and duration of inundation events and flooding and with the fluctuation of the water level (Wolf et al., 2001). Main peat-forming systems are bogs, fens, springs and brook valleys. Within these systems, conditions can vary within a rather short period. The peat-forming system can be described as a complex of nested cycles (Fig. 8).

\section{Bioactivity in bogs and rain-fed floating fens}


In fens, bogs and springs the fluctuation of the water table is rather small. Decomposition in oxygen-poor circumstances (a constant state of water saturation) is mainly directed by anaerobic microorganisms (Scheffer et al., 1982). As a result, the level of mineralization, humification and mixing of the organic material is very low (Fig. 9). The accumulation of almost unaltered plant remains is the main humus forming process here. The humus form in this kind of environment is mainly a Fibrimoor. After a sudden desiccation caused by peat mining activities or drainage the biological activity stays low and a "fossil" Fibrimoor persists (Stortelder et al., 1998).

Fibrimoors can also exist for a rather short period in eutrophic peaty environments like floating fens composed of reeds and sedges. Most typical Fibrimoors of the more durable kind evolve to rain-fed bogs and rain-fed isolated areas within floating fens. In these fully water-saturated humus forms, without large seasonal fluctuations, earthworm and enchytraeid (potworm) activity is almost nil, because of lack of oxygen. In addition, the $\mathrm{pH}$ in some acid parts of bogs is too low to sustain a population of earthworms and potworms (Graefe and Beylich, 2003). In these acid and watersaturated environments sphagnum mosses dominate all types of chemical and physical processes. Slight drainage leads to some increased bioactivity (Fig. 9). In these drained acid circumstances, enchytraeids like Cognettia sphagnetorum will colonize and become active (Beylich and Graefe, 2002). Only after a long time, poor and acid amorphic Saprimoders will develop (Jongerius and Pons, 1962). A poor Mesimoor acts as an intermediate phase (Fig.10). Going toward less acid areas, a condition of slight drainage allows the arrival of animal populations in the organic topsoil, leading to the formation of an Amphimoor, which evolves to a Saprimoor in base-rich environments. Under boreal climate there are a lot of oligotrophic organic soils on a very deep peat which evolve, after artificial or natural drainage followed with the development of coniferous forests, towards a typical terrestrial Mor while untransformed gOF, gOH and nozHS hydromorphic horizons subsist under the water table (Chertov, personal communication).

In mesotrophic and slightly eutrophic environments with small water table fluctuations, Fibrimoors are formed from more readily decomposable plant residues like sedges, often in combination with reeds, wood remnants (willow) and sometimes with some content of mineral soil particles. After only slight drainage (a few $\mathrm{cm}$ ), enchytraeids may become active (Healy, 1987; Cole et al., 2002; Laiho, 2006) and the Fibrimoor develop to a Mesimoor (Fig. 10). If the average water level is lowered by more than $10 \mathrm{~cm}$, lumbricids may also become active if they are present in the immediate environment. Mainly endogeic and epigeic earthworms are active in the range of Mesimoor (Fig. 9). The result is a growing, initially thin, black bed of well-decomposed and structured fine humus. In the event of further drainage, this will transform Mesimoor into Amphimoor and Saprimoor in which even anecic earthworms can become active (Fig. 9).

In vast areas of reclaimed fens and mires in lowland parts of northern Germany and in the Netherlands, Amphimoor and Saprimoor are the dominant humus forms. Although groundwater fluctuations are larger in drained fens of meadows and woods than in untouched fens, moisture regimes are never entirely dry. Such an environment remains favourable for enchytraeids and earthworms. On the other hand, periods of high water levels (aboveground level) can be temporarily unfavourable to enchytraeids and earthworms. However, earthworms can survive these anaerobic periods by migration, diapausing cocoons and other strategies (Plum, 2005). 
Lowering of the water table does not always lead to a much higher activity of soil organisms. Especially in peaty humus forms which are originally influenced by nutrient- and calcium-rich water as in lake shores, $\mathrm{pH}$ can drop due to the increasing influence of infiltrating rainwater. On some less eutrophic sites, a rainwater lens can even develop which favours the growth of sphagnum species. These layers of living and decayed sphagnum mosses act as a sponge which promotes the development of a thin water-saturated oligotrophic humus layer with low bioactivity. Although for a short time, layers with low and medium bioactivity can coexist (Amphimoor).

\section{Bog and fen vegetation dynamics}

Fens and bogs often show dynamic relationships (Fig. 10). In temperate climates (not mountain, not boreal, not arid, not tropical), where biological activity is moderate during most of the year, the formation of bogs succeeds that of fens (Hughes and Barber, 2003). Starting with base-rich water, fed by groundwater, a pond (whether issued from natural or man-made cavities) appears after its bottom has been made impermeable (sealing) through the sedimentation of very fine mineral particles (clay). Further in timethe pond is totally or at least partly invaded with nutrientexacting vegetation (reeds, sedges), with concomitant sedimentation of organic matter, which may accumulate if anaerobic conditions are maintained, and thus form peat under water (Hughes and Barber, 2003). Peat immobilizes a great amount of nutrients, progressively impoverishing and acidifying pond water, which may induce in the course of time a vegetation change, the environment becoming more favourable to cottongrass (Eriophorum) and sphagnum mosses. The progressive establishment and thickening of sphagnum carpets, whether starting from the shore or from plant rafts (often caused by degassing of the organic bottom, personal observations, JFP), generates the formation of a bog, fed by rain and by the capillary ascension of water through a thick moss carpet acting as a nutrient-capturing sponge, with concomitant acidification of the environment (Moore et al., 2004). The pond may remain at the stage of raised bog for centuries if not millenaries, despite climate shifts, if not drained or exploited by man (Lamentowicz et al., 2008). Several scenarios of vegetation dynamics are possible, which have been described in detail on the base of space-for-time substitution studies (Walker, 1970) and more recently through the stratification of micro- and macrofossils (Hughes and Dumayne-Peaty, 2002). Terrestrialization of bogs has been often postulated but this commonly reported scheme of the forest climax has been questioned by Klinger (1996) on the base of a wide examination of published and unpublished literature. However, terrestrialized bogs are difficult to find in nature by botanists or foresters (but not by soil scientists) because naturally afforested bogs resemble ordinary well-drained forests, as this has been observed while mapping the soils in taiga forests (Chertov, 1981).

\section{Springs and brook valleys}

At the more base-rich and more mineral end of the Semiterrestrial spectrum, such as springs and groundwater-fed wet brook valleys, the accumulation of organic matter is not spectacular and 
most bioactivity is due to actinomycetes (Scheffer et al., 1982). In these circumstances, rather rich Anmoor humus forms will develop. Under the influence of lower $\mathrm{pH}$ and lower calcium availability, a much poorer Anmoor will form, the activity of actinomycetes being decreased (Figs. 9 and 10).

In wet brook valleys, fluctuations are somewhat wider, which enables some annelids to be active in periods of lower water levels. Normally in brook valley systems water level fluctuations enable enchytraeids and earthworms to transform the Mesimoor into a Saprimoor. Earthworms have different strategies to cope with anaerobic periods during flooding (diapause, migration).

Enchytraeids are less adapted to prolonged periods of inundation (Healy, 1987; Plum, 2005). Due to a larger content of mineral component (thin layers of sandy sediments as well as clay) in drained brook systems, Mesimoors can develop to Hydromulls by way of oxidation and mineralization of the organic fraction (Stortelder et al., 1998). Like in fens, drainage does not always lead to better conditions for decomposing organisms (Oliver et al., 1999; Van Diggelen et al., 2006). Isolation from the rather rich brook water can lead to a growing influence of rainwater, especially when it stagnates on a loamy layer with low permeability, which occurs quite often in these systems. The development of Amphimoor humus forms is also a possibility here. In extreme circumstances, Mesimoors and Saprimoors can even develop into acid Fibrimoors in the long-term, forming a small-scale bog system within the brook valley (Fig. 11).

\section{References}

Beylich, A., Graefe, U., 2002. Annelid coenoses of wetlands representing different decomposer communities. In: Broll, G., Merbach, W., Pfeifer, E.M. (Eds.), Wetlands in Central Europe. Springer, Berlin, pp. 1-10.

Chertov, O.G., 1981. Ecology of Forest Lands. Soil Ecological Investigation of Forest Sites. Nauka Leningrad (in Russian).

Cole, L., Bardgett, R.D., Ineson, P., Hobbs, P.J., 2002. Enchytraeid worm (Oligochaeta) influences on microbial community structure, nutrient dynamics and plant growth in blanket peat subject to warming. Soil Biol. Biochem. 34, 83-92.

Graefe, U., Beylich, A., 2003. Critical values of soil acidification for annelid species and the decomposer community. Newslett. Enchytraeidae 8, 51-55.

Healy, B., 1987. The depth distribution of Oligochaeta in an Irish quaking marsh. Hydrobiologica 155, 235-247.

Hughes, P.D.M., Barber, K.E., 2003. Mire development across the fen-bog transition on the Teifi floodplain at Tregaron Bog, Ceredigion, Wales, and a comparison with 13 other raised bogs. J. Ecol. 91, 253-264.

Hughes, P.D.M., Dumayne-Peaty, L., 2002. Testing theories of mire development using multiple successions at Crymlyn Bog West Glamorgan, South Wales, UK. J. Ecol. 90, 456-471. 
Jongerius, A., Pons, L.J., 1962. Soil genesis in organic soils. Boor en Spade 12, 156-177.

Klinger, L.F., 1996. The myth of the classic hydrosere model of bog succession. Arct. Alp. Res. 28, 1-9.

Laiho, R., 2006. Decomposition in peatlands: reconciling seemingly contrasting results on the impacts of lowered water levels. Soil Biol. Biochem. 38, 2011-2024.

Lamentowicz, M., Cedro, A., Gałka, M., Miotk-Szpiganowicz, G., Mitchell, E.A.D., Pawlyta, J., 2008. Last millennium palaeoenvironmental changes from a Baltic bog (Poland) inferred from stable isotopes, pollen, plant macrofossils and testate amoebae. Palaeogeogr. Palaeoclimatol. Palaeoecol. 265, 93-106.

Moore, T., Blodau, C., Turunen, T., Roulet, N., Richard, P.J.H., 2004. Patterns of nitrogen and sulfur accumulation and retention in ombrotrophic bogs, eastern Canada. Global Change Biol. 11, 356-367.

Oliver, D., Blume, H.P., Kappen, L., Kutsch, W.L., Middelhoff, U., Wötzel, J., 1999. Microbial processes and features of the microbiota in histosols from a black alder forest. Geomicrobiol. J. 16, 6578.

Plum, N., 2005. Terrestrial invertebrates in flooded grassland: a literature review. Wetlands 25, 721737.

Scheffer, F., Schachtschabel, P., Blume, H.P., Hartge, K.H., Schwertmann, U., 1982. Lehrbuch der Bodenkunde. Enke, Stuttgart.

Stortelder, A.H.F., Hommel, P.W.F.M., De Waal, R.W., 1998. Broekbossen. Bosecosystemen van Nederland (deel 1). KNNV, Utrecht.

Van Delft, B., Kemmers, R., De Waal, R.W., 2002. Ecologische typering van bodems onder korte vegetaties: hethumusprofielals graadmeter voor standplaatsontwikkeling. Landschap 19, 152-164.

Van Diggelen, R., Middleton, B., Bakker, J., Groojans, A., Wassen, M., 2006. Fens and floodplains of the temperate zone: present status, threats, conservation and restoration. Appl. Veg. Sci. 9, 157-162.

Walker, D., 1970. Direction and rate in some British post-glacial hydroseres. In: Walker, D., West, R.G. (Eds.), Studies in the Vegetational History of the British Isles. Cambridge University Press, Cambridge, pp. 117-139.

Wolf, R.J.A.M., Stortelder, A.H.F., De Waal, R.W., 2001. Ooibossen. Bosecosystemen van Nederland (deel 2). KNNV, Utrecht.

Zanella, A., Jabiol, B., Ponge, J.F., Sartori, G., De Waal, R., Van Delft, B., Graefe, U., Cools, N., Katzensteiner, K., Hager, H., Englisch, M., 2011a. A European morphofunctional classification of humus forms. Geoderma 164, 138-145.

Zanella, A., Jabiol, B., Ponge, J.F., Sartori, G., De Waal, R., Van Delft, B., Graefe, U., Cools, N., Katzensteiner, K., Hager, H., Englisch, M., Brêthes, A., Broll, G., Gobat, J.M., Brun, J.J., 
Milbert, G., Kolb, E., Wolf, U., Frizzera, L., Galvan, P., Kõlli, R., Baritz, R., Kemmers, R., Vacca, A., Serra, G., Banas, D., Garlato, A., Chersich, S., Klimo, E., Langohr, R., 2011. European Humus Forms Reference Base. https://hal.archives-ouvertes.fr/hal-00541496 (Accessed 28 February 2017). 


\section{Figure captions}

Fig. 1. Epihisto and Hydro intergrades, along a gradient going from Histic to Terrestrial humus systems.

Fig. 2. gOL horizon. In water litter becomes in a first time (5 months or less) brown and later decidedly black.

Fig. 3. gOF Horizon. As in dry conditions, the percentage of recognizable remains is comprised between 10 and $70 \%$ of the volume of the horizon.

Fig. 4. anA horizon. The anA horizon often looks like an organic A horizon but without structure. In fact water destroyed the structure which had been created by earthworms which left the horizon after prolonged submersion.

Fig. 5. Epihisto Euanmoor. Diagnostic horizons: gOL, gOF, anA.

Fig. 6. Example of transition without Epihisto intergrades, where Terrestrial becomes Hydro and Histic humipedons, skipping the Epihisto intergrade facies. This situation is common along pond or basin sides. Thin anA, HS Histic horizons are possible, or darker mixed Histic anA/Hydro $\mathrm{gA}$, but not superposition of $\mathrm{gA}$ and $\mathrm{H}$ horizons.

Fig. 7. Second level of classification of Histic systems and forms. The first two lines correspond respectively to SYSTEMS (first level) subdivided in FORMS (second level). Example of subdivision of the Anmoor system: Euanmoor, Saprianmoor, Limianmoor. Other lines show diagnostic horizons superposed as in a real profile. Both presence/absence and relative thickness (dominance) of each diagnostic horizon are important for classifying Histic systems and forms. Epihistic = prefix " $g$ " used if presence of hydromorphic horizons (gA, gAE). These hydromorphic horizons are not present in a fixed position in the profile but can be generated at different depth levels, sometimes even parting into a mainly organic and an organicmineral horizon. The presence of gOL and/or gOF horizons is not sufficient for using the prefix Epihistic; the presence of gOH or/and gA or/and gnozA or/and gAE is sufficient for using the Epihistic prefix; possible = not always present or thickness $<2 \mathrm{~mm}$; dominant = horizon thicker than each other single horizon of the series. Nota: The relative thickness of the horizons is graphically indicated (multi-lines layer) in the table (grey area) because it influences the result of the classification, ex: Fibrimoor $=\mathrm{HM}>\mathrm{HF}>$ nozHS; Mesimoor $=\mathrm{HM}$ $>$ nozHS > HF.

Fig. 8. Interacting ecological factors in Semiterrestrial humus forms.

Fig. 9. Relationships between $\mathrm{pH}$ and water saturation and bioactivity. Modified after Beylich and Graefe (2002).

Fig. 10. Development of humus forms in fens and bogs (large extended systems characterized by a dominant process of sedimentation, large floodplains) according to water quality and quantity. The profiles shown are just an indication and also include layers below the control section (first $40 \mathrm{~cm}$ ). Modified after Stortelder et al. (1998) and Van Delft et al. (2002). In the course of time, a nutrient-rich humipedon can lose its mineral bases because of the 
accumulation of plant organic remains under slow decomposition, in submerged anaerobic conditions. In addition, the soil can lose its groundwater and be fed rather by rain water; little by little, sphagnum moss takes the place of the original meadow and a base-rich fen thus becomes a base-poor bog.

Fig. 11. Development of humus forms in brook valley systems (small systems, like small rivers, brooks, streams and floodplains). The profiles are just an indication and also show layers beneath the control section. Modified after Stortelder et al. (1998) and Van Delft et al. (2002). 


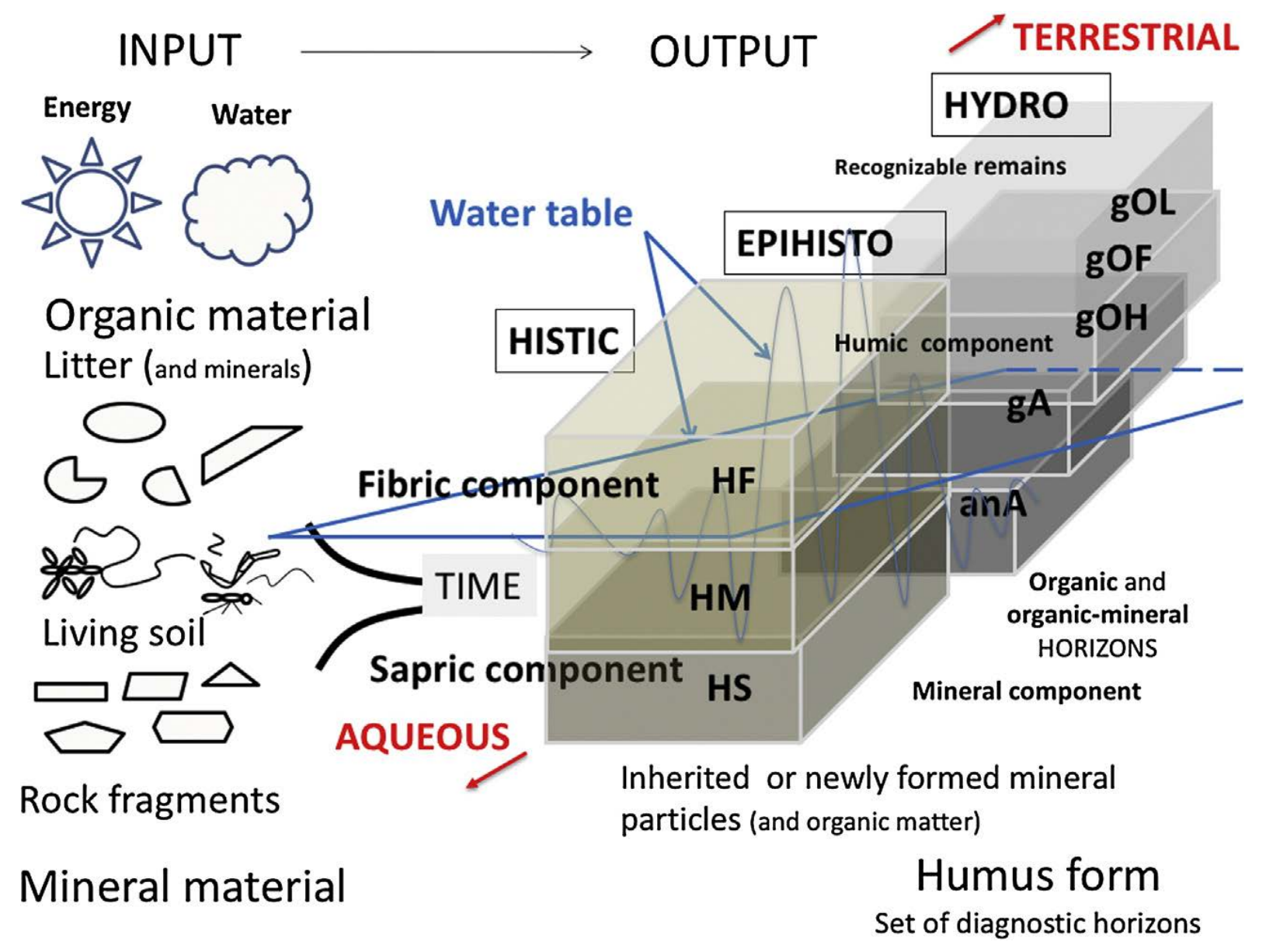

Fig. 1 


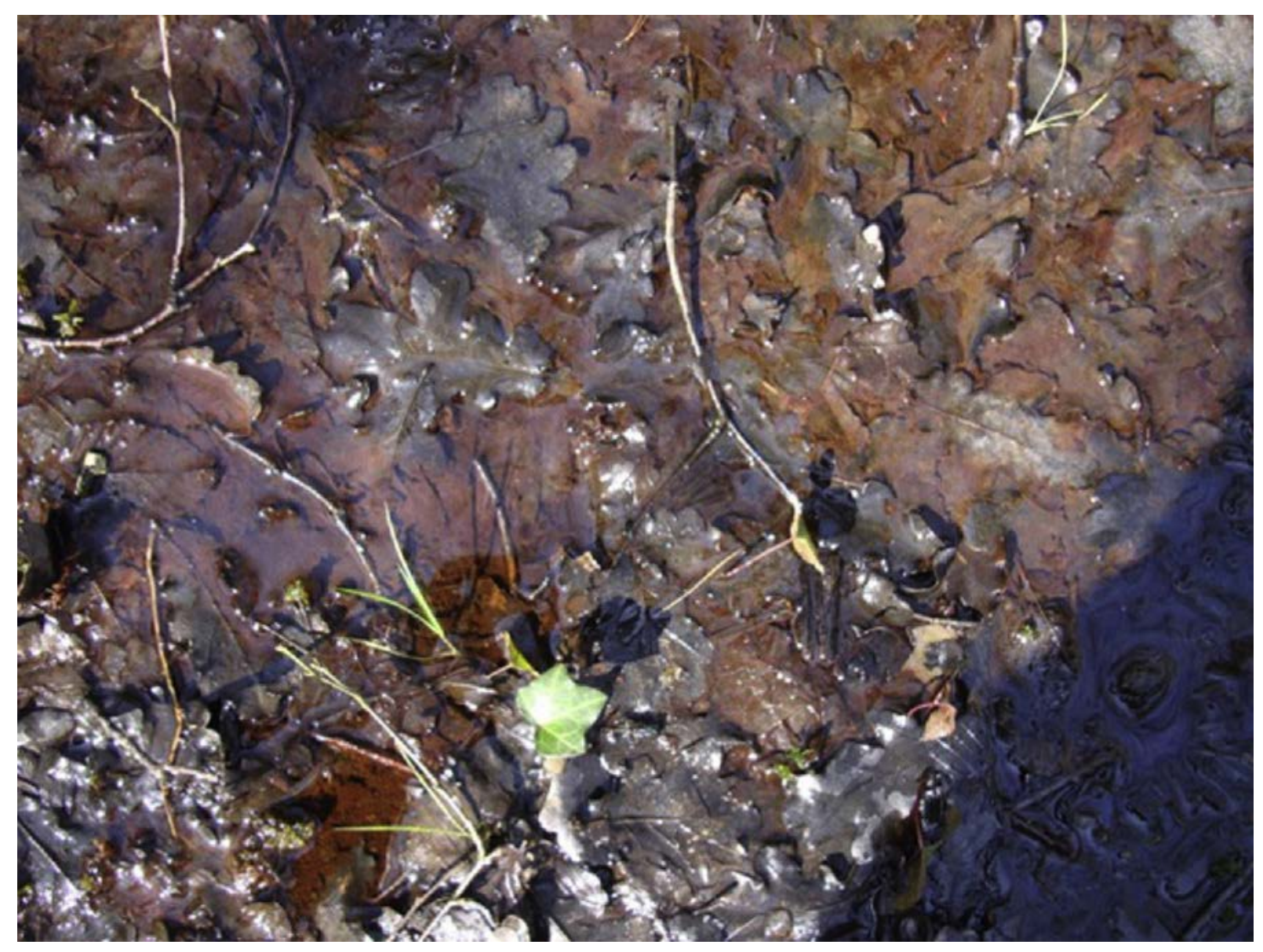

Fig. 2 


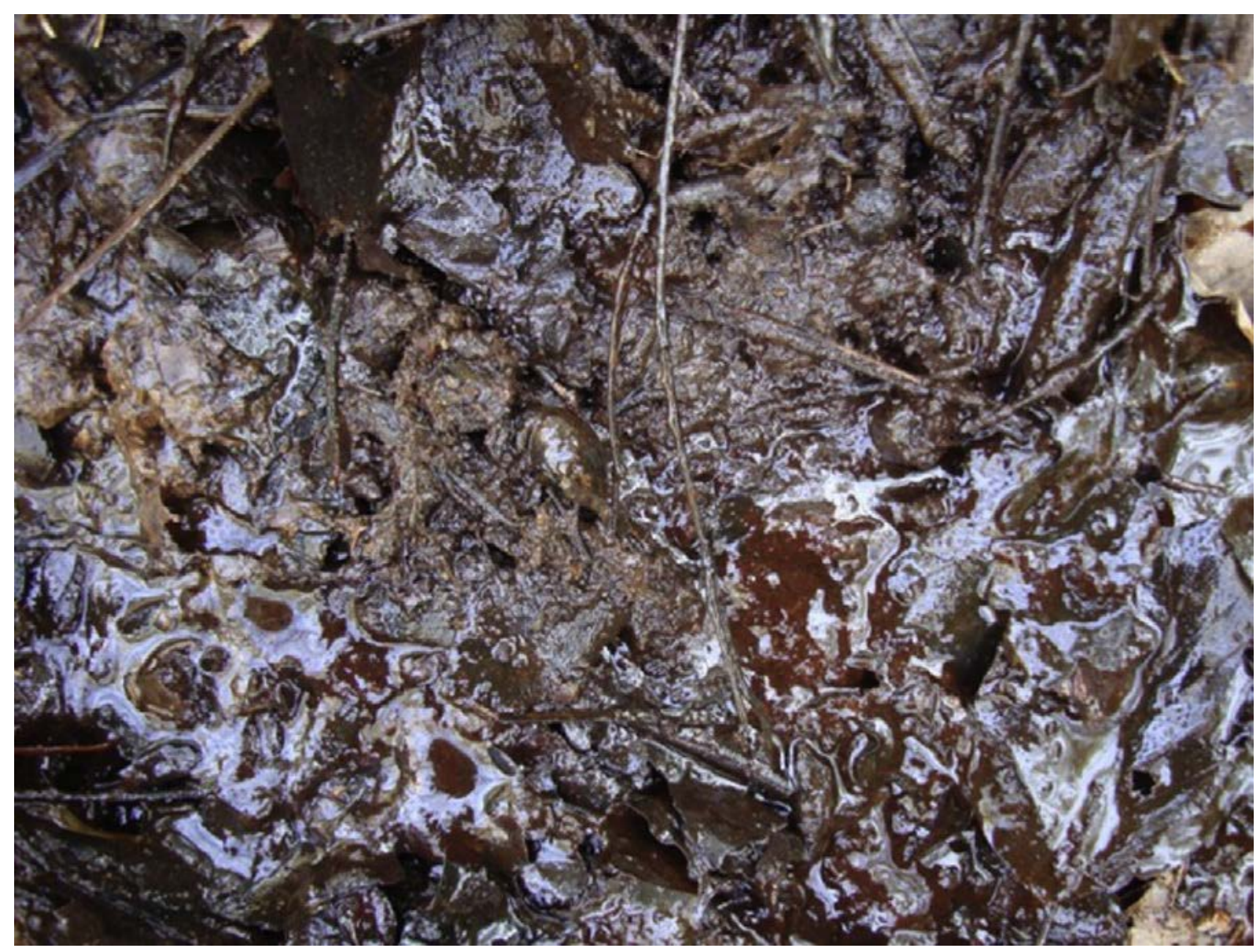

Fig. 3 


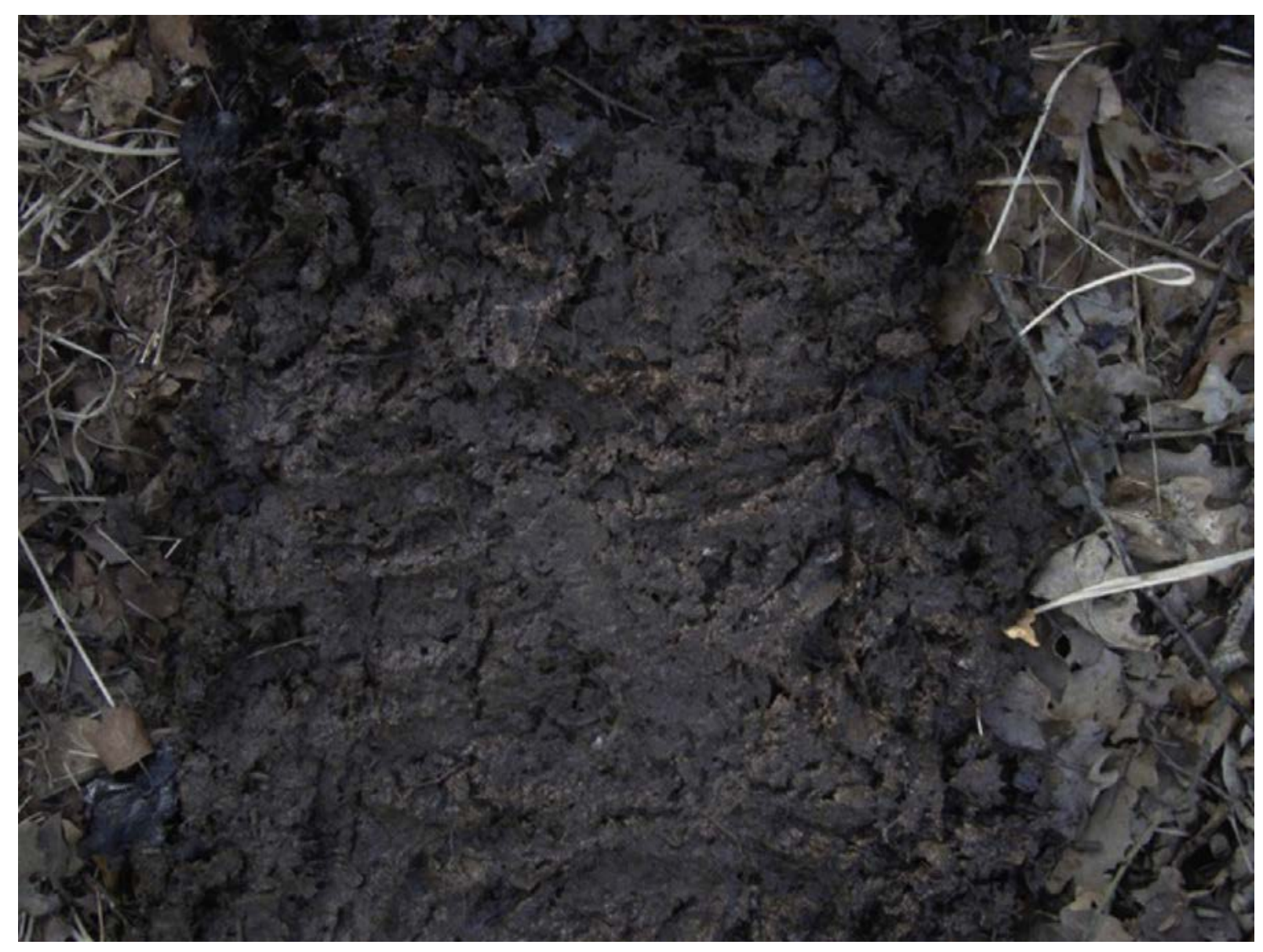

Fig. 4 


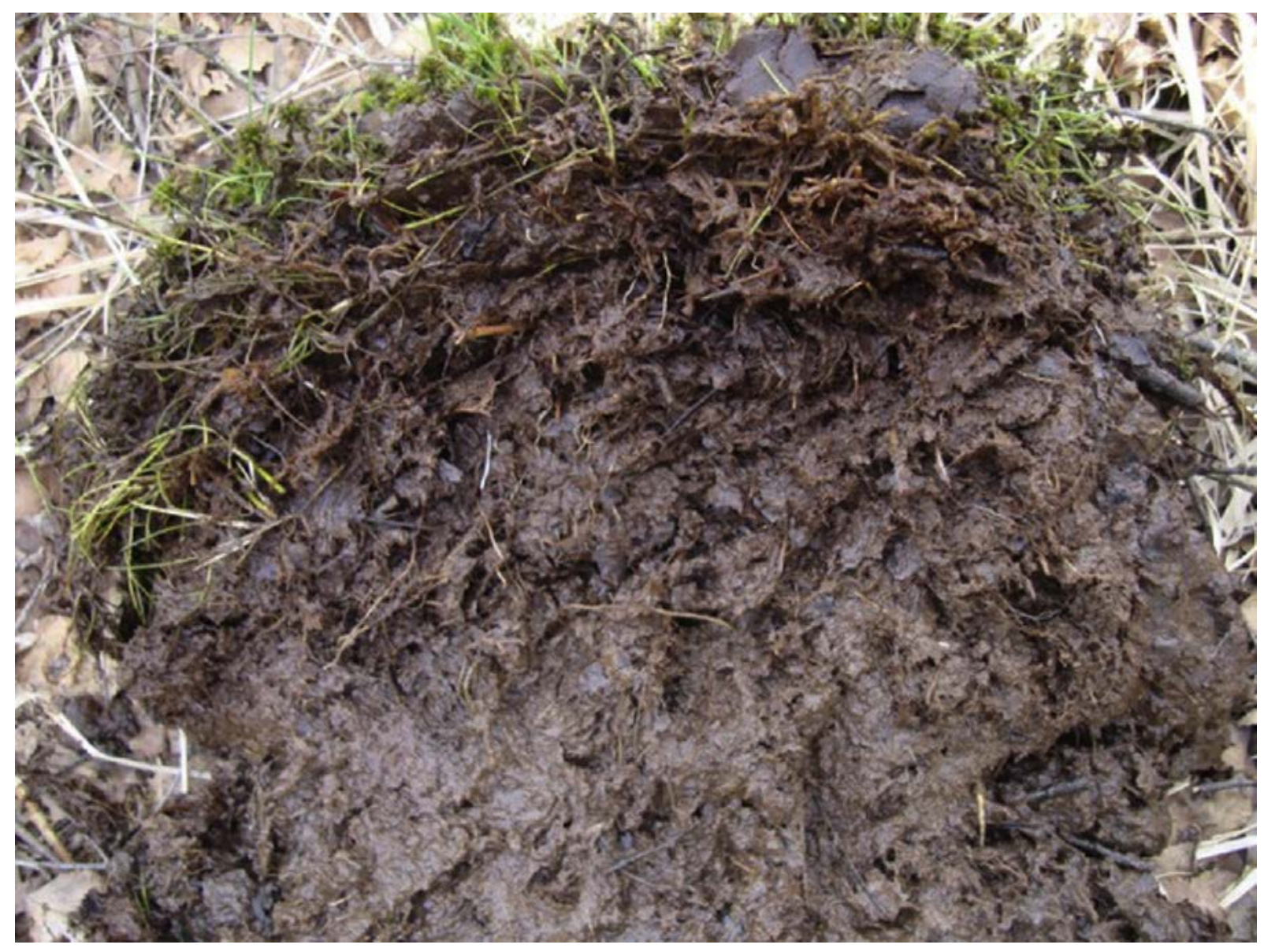

Fig. 5 


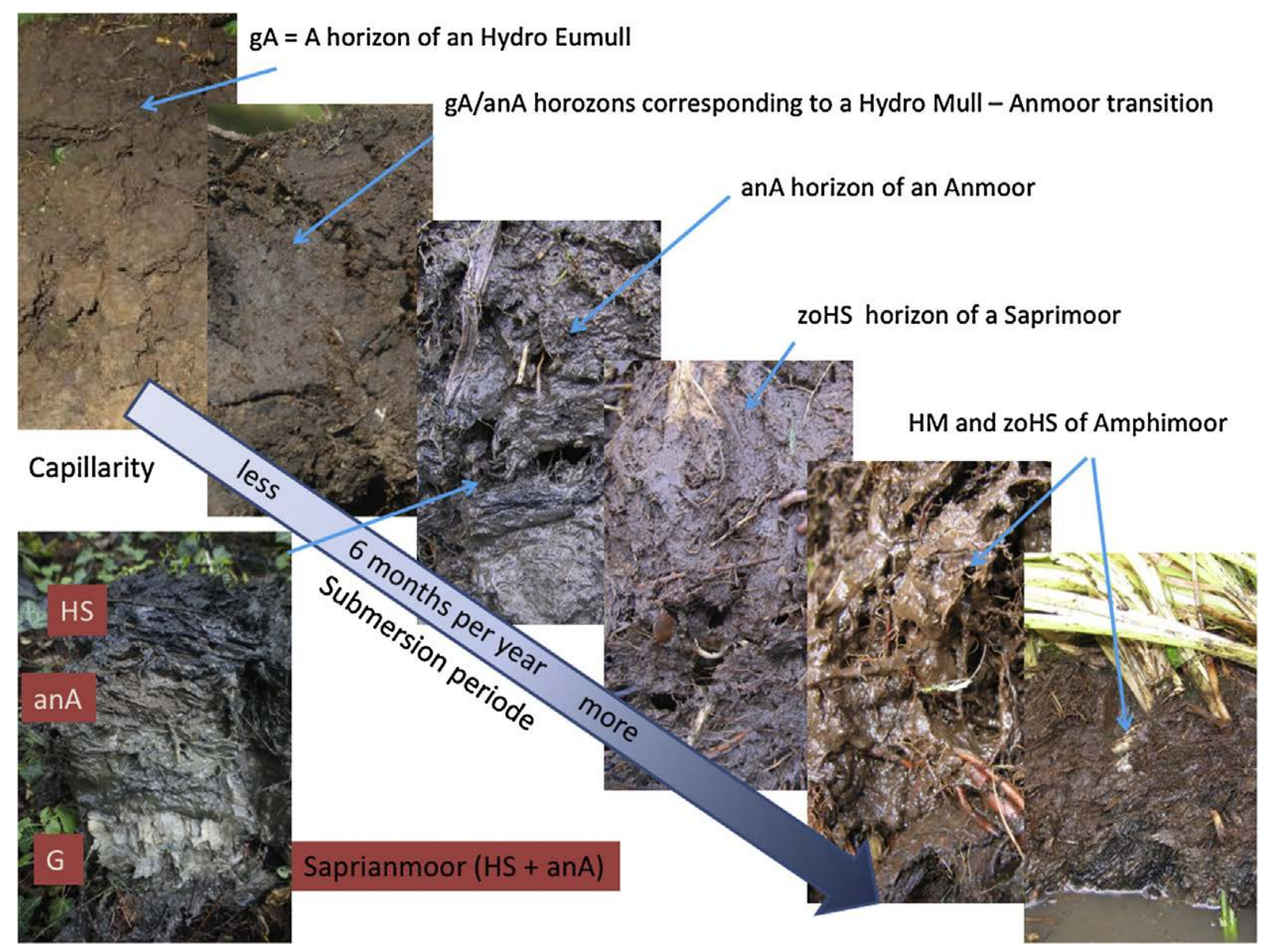

Fig. 6 


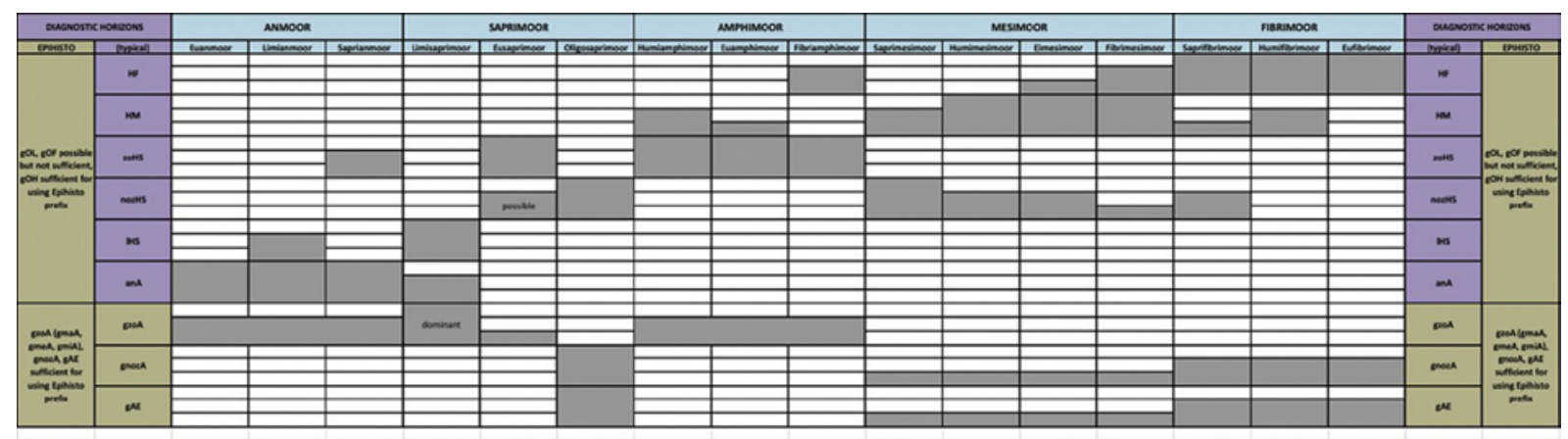

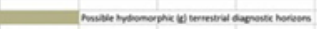

Fig. 7 


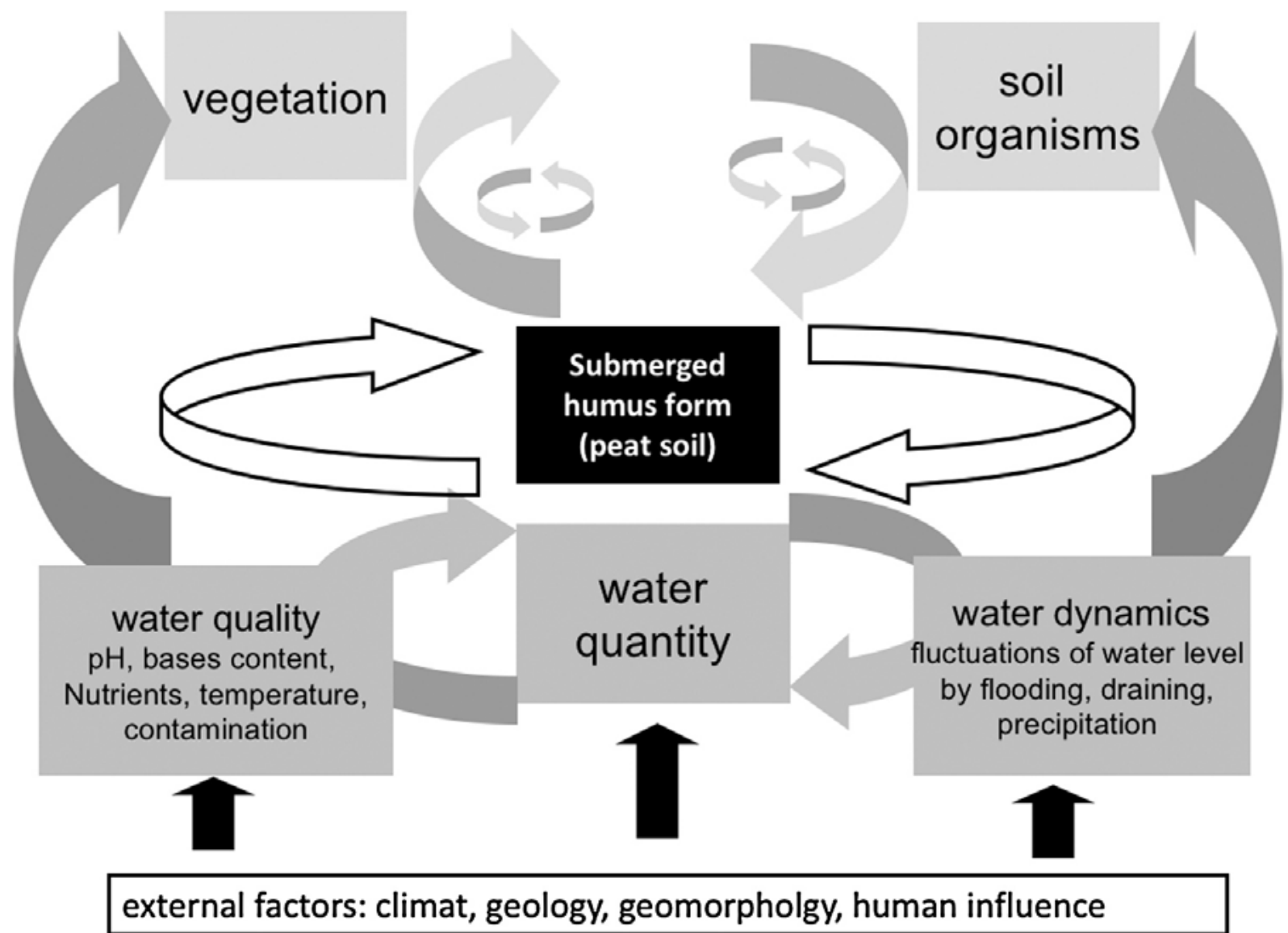

Fig. 8 


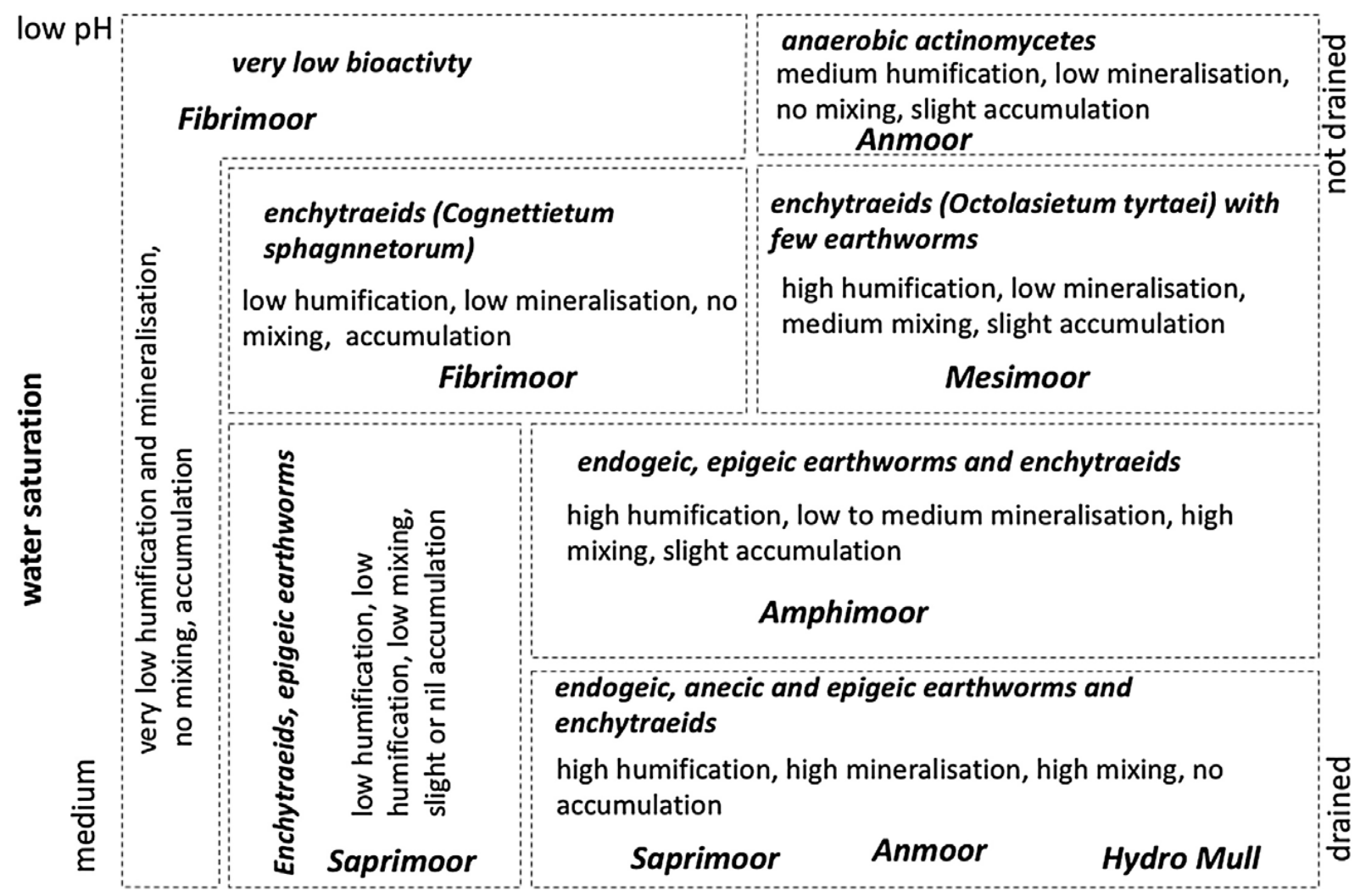

Fig. 9 


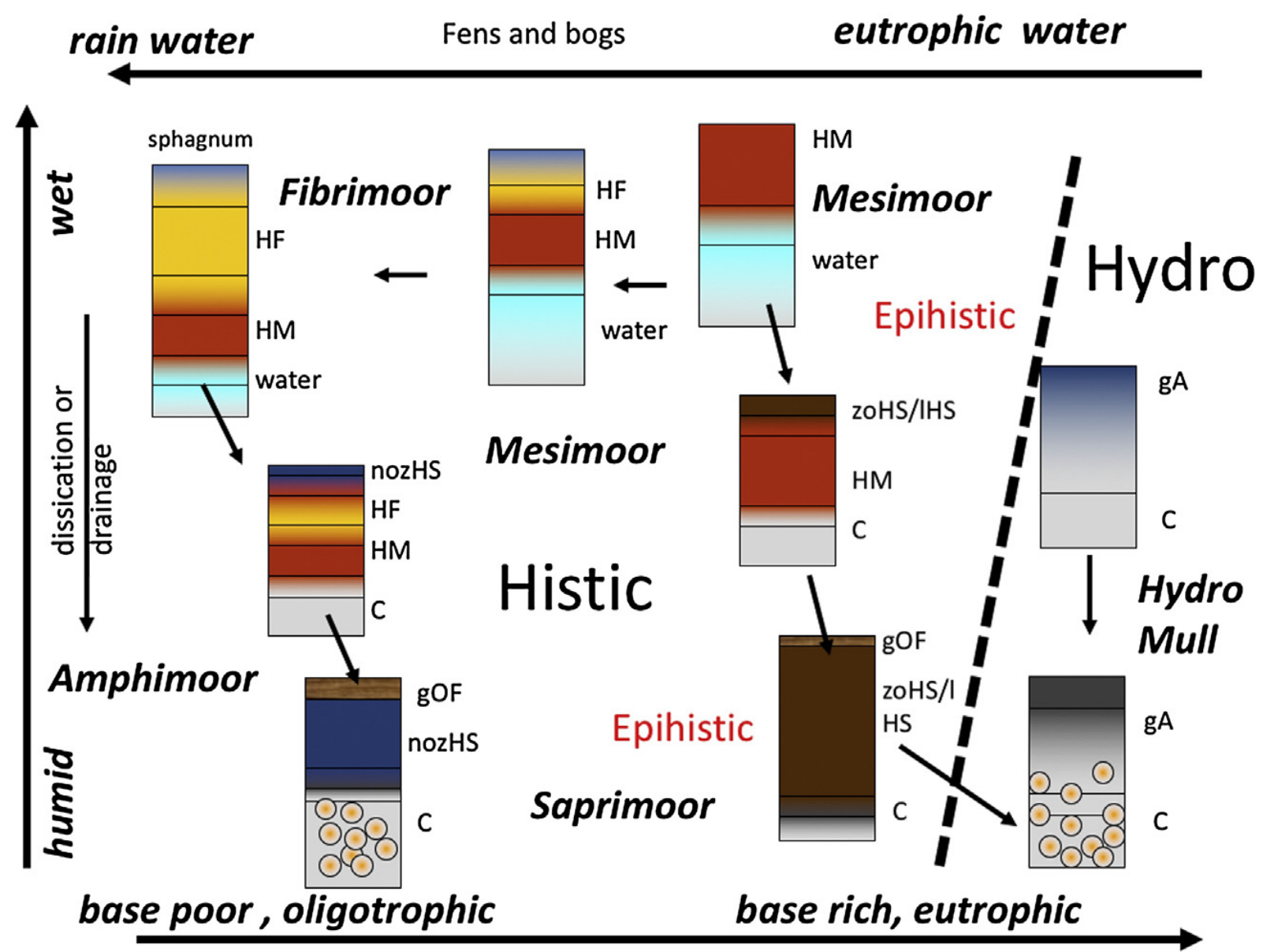

Fig. 10 


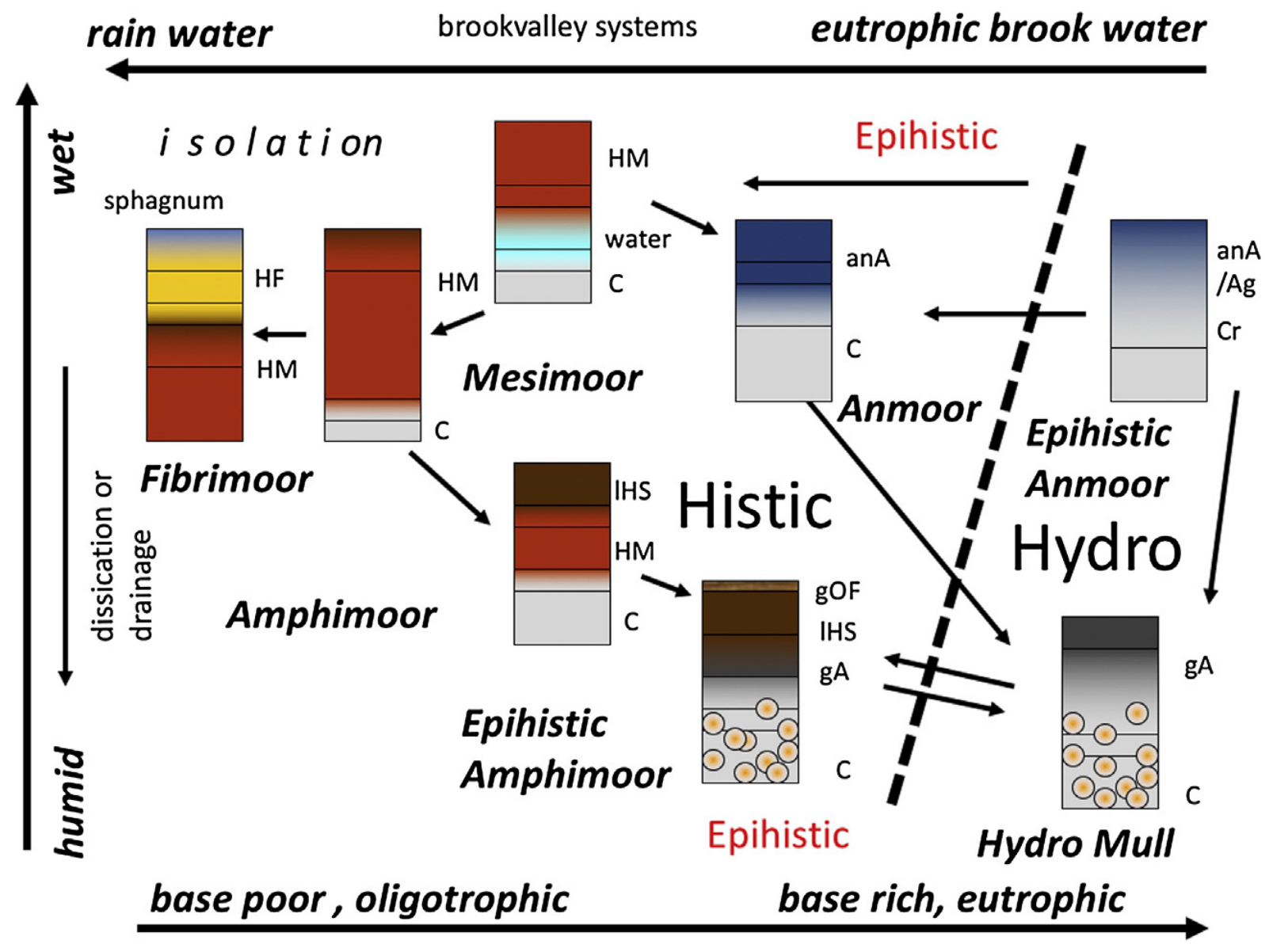

Fig. 11 